\title{
THE EFFECTS OF THE COVID-19 OUTBREAK ON TOURISM IN SARAJEVO CANTON
}

\author{
Almir Peštek \\ Lejla Lazović-Pita \\ Velma Pijalović
}

https://doi.org//10.20867/tosee.06.41

\begin{abstract}
Purpose - The purpose of this paper is to examine the effects that COVID-19 outbreak has had on tourism in Bosnia and Herzegovina $(\mathrm{BiH})$ and specifically in Sarajevo Canton.

Methodology - A survey was conducted in two rounds in March and September 2020, and responses were obtained from 126 running businesses from the tourism in Sarajevo Canton about the actual and expected consequences that COVID-19 outbreak has had on their business. The respondents were asked questions about the effects that COVID-19 has had on their business operations during the first six months of COVID-19 outbreak and their expectations for the future. The questions also included issues related to the government interventions and stimulus packages to overcome the effects of COVID-19 to ensure the sustainability of the tourism in Sarajevo Canton.

Findings - Our results show that all businesses have faced a significant downturn in their business operations and had to undertake different measures and activities internally to overcome (and survive) the negative effects of the COVID-19 pandemic. The results also show that there is very low level of satisfaction with the government interventions to tourism.

Contribution - The findings illustrate and confirm many flaws in tourism system in Sarajevo Canton and $\mathrm{BiH}$ where tourism has been developing organically and without proper integration of the private and public industry. Our findings can be used for planning purposes and improvement of the situation during COVID-19 and post-COVID-19 period.
\end{abstract}

Keywords: tourism, Sarajevo Canton, COVID-19, crisis, government interventions.

\section{INTRODUCTION}

According to the UNWTO (2020), in the last twenty years (2000-2019), the tourism has had more-or-less steady growth and was a third largest export industry of the global economy. However, with the outbreak of COVID-19 in 2020 which has had a deep impact on travelling worldwide, global export revenues from tourism could fall by $\$ 910$ billion to $\$ 1.2$ trillion (UNWTO 2020). Similar to global trends, Bosnia and Herzegovina $(\mathrm{BiH})$ as a small transition country has also had an increase in the growth of tourism over 2000-2019 period. However, in 2020 tourism was expected to plummet. First available data in $\mathrm{BiH}$ revealed a sharp decline in the number of incoming tourist arrivals and overnight stays in the first half of 2020. In fact, in $\mathrm{BiH}$, the total number of incoming tourist arrivals and nights in 2019 in comparison to 2014 increased by 95 percent and 98 percent, respectively.

Sarajevo Canton and Sarajevo as the country's capital in the period prior to pandemic has recorded a significant increase in the number of visiting tourists and their stays. In 
ToSEE - Tourism in Southern and Eastern Europe, Vol. 6, pp. 607-621, 2021.

A. Peštek, L. Lazović-Pita, V. Pijalović: THE EFFECTS OF THE COVID-19 OUTBREAK ...

fact, over 2014-2019 period, Sarajevo Canton has generated on average, more than 50 percent of all incoming tourist arrivals and nights in Federation of Bosnia and Herzegovina $(\mathrm{FBiH})$ and more than 36 percent in $\mathrm{BiH}$ (2014-2019). So, the purpose of this paper is to examine the effects that COVID-19 outbreak has had on tourism in $\mathrm{BiH}$ and specifically in Sarajevo Canton through a method of survey. We have conducted a survey in two rounds in Sarajevo Canton: in March 2020 at the outbreak of COVID-19 pandemic and obtained 233 responses from running businesses, and the same survey again in September 2020 and obtained responses from 126 running tourism-related businesses in Sarajevo Canton (hotels, hostels, travel agents, short term rentals, tour guides, restaurants, rural households, transportation services, etc.). The difference in the sample goes to that fact that most businesses were forced to close in September compared to the situation in March 2020. The respondents were asked about the actual and expected consequences that COVID-19 outbreak has had on their business. Our results reveal a gloomy picture of a significant downturn in the tourism business operations and a very low level of satisfaction with the government interventions to tourism. So, after the introduction, the paper is organised around four chapters. After a brief literature review and the analysis of the position of Sarajevo Canton in the period 2014-2019, we present the methodology and the results of the two rounds of the survey. We conclude with a set of recommendations and suggestions on how to improve the current situation in the tourism in $\mathrm{BiH}$ during COVID-19 and post-COVID-19 period.

\section{LITERATURE REVIEW}

The tourism has been, together with the health industry, the most severely hit industry during the COVID-19 pandemic. In fact, the downturn in the tourism has marked the entire 2020 with the shred of hope for tourism recovery in 2021 put in the development of vaccines and the process of mass vaccination of the general population around the world. Even though countries in the European Union (EU) as well as non-EU countries have tried to implement several monetary and fiscal counter-recession measures in order to tackle the effects of the pandemic, the struggle to overcome the economic effects of the pandemic are still present at large.

The literature regarding the effects of the pandemic on tourism is steadily increasing over the past year. The Web of Knowledge scientific database with three keywords, namely, tourism, COVID or coronavirus in title and government in the topic section reveals some 23 scientific papers where twelve are relevant for our analysis. In terms of developed methodology, some eight use a questionnaire as a method of assessing the impact of the pandemic on tourism or its specifics, while the remaining four deal with the sustainability issues in tourism, associated risks that pandemic brought in the tourism or the public tourism policies that were implemented in previous pandemics.

Starting from the analysis of the global impact that pandemic had on tourism, works of Galvani et al. (2020) and Ioannides and Gyimothy (2020) discuss the issues related to sustainability of tourism and moving towards the sustainable tourism during and after the pandemic. In that sense, the implemented public policies as well as economic stimulus packages provided to tourism-related businesses are of great importance. The paper from Khalid et al. (2021) builds upon the works from Elgin et al. (2020) in the 
ToSEE - Tourism in Southern and Eastern Europe, Vol. 6, pp. 607-621, 2021.

A. Peštek, L. Lazović-Pita, V. Pijalović: THE EFFECTS OF THE COVID-19 OUTBREAK ...

analysis of the impact and the applied economic stimulus packages designed to mitigate the negative effects of the pandemic, including its impact on travel and tourism. The results from Khalid et al (2021) indicate that the size of the tourism is positively associated with the size of the economic stimulus packages (both fiscal and monetary policy). In terms of the effects of the public tourism policies, Apaza-Panca et al. (2020) discuss and find the scarcity of public tourism policies proposed and implemented in tourism magazines, with an unclear methodology applied and implemented as a key management tool.

Most scientific work about the impact of the pandemic on tourism is country specific. For example, Cai et al. (2021) discuss the impact that pandemic had in Japan, specifically on ryokans and green ryokans. Knight et al. (2020) analyze the results of a conducted survey among practitioners working in four tourism and hospitality industries in Wuhan, China in the midst of the pandemic outbreak. After a first gloomy outlook, the authors provide an overview of the future strategies/directions and highlight the significance of active government action and policies to overcome the effects of the pandemic. Similarly, by using a survey, Foo et al. (2020) analyze the impact that the pandemic had on tourism in Malaysia and the stimulus packages offered by the Malaysian government. Quang et al. (2020) assess the impact that pandemic had on Vietnamese tourism by using a method of a survey and concludes that Vietnamese tourism and Vietnamese government encouraged domestic tourism in the second stage to overcome the effects of the pandemic. Important policy-related issues were concluded and reflected through the industry move towards the restructuring of various practices to help prevent and mitigate the risks to the tourism posed by future crises. Along the lines of minimizing risks, especially health-related risks of future travelling, attracting future tourists, competition between the destinations/countries etc., the paper from Grech et al. (2020) assesses the measures and necessary joint action of the government and the public health industry in the actions against the future pandemic outbreaks. The recovery could be slow and will be primarily driven by the strength of the economic recovery (McKinsey \& Company 2020).

Other papers analyze specifics within the tourism, for example the position of the tourism enterprises and workers in the undeclared economy in the EU (Williams 2021) or the hostile and negative responses of the online public to the crisis in the tourism within Poland (Kopytowska and Krakowiak 2020).

To our knowledge, the analysis of the impact of the pandemic to tourism in $\mathrm{BiH}$ has not been conducted or researched. Similar to most countries around the world, $\mathrm{BiH}$ tourism turned to the government for seeking economic stimulus packages to overcome the effects of the pandemic. Two entity governments, FBiH and Republika Srpska (RS) have conducted several fiscal stimulus measures to overcome the effects of the pandemic which were provided as a support to the population and the companies (OECD, 2020a; $2020 \mathrm{~b}$ ). The overall support was reflected in several activities, for example, establishment of funds to help entrepreneurs (or certain industries most affected by the crisis, direct assistance to individuals in certain industries in terms of financing SSC, etc.). For the tourism specifically, the RS government implemented additional support to tourism in terms of announced 20,000 tourism vouchers (approx. EUR 50 per adult) that were planned to be given out and used to co-finance accommodation costs at any 
ToSEE - Tourism in Southern and Eastern Europe, Vol. 6, pp. 607-621, 2021.

A. Peštek, L. Lazović-Pita, V. Pijalović: THE EFFECTS OF THE COVID-19 OUTBREAK ...

destination in the RS, provided that the stay lasts a minimum of 3 nights (OECD 2020b, 67). The $\mathrm{FBiH}$ government passed a Decree aimed at mitigating the economic consequences of the COVID-19 pandemic in four industries where tourism received the greatest support (15 million EUR, OECD 2020b, 72). In this paper we wanted to evaluate the perceptions and attitudes of the tourism stakeholders in Sarajevo Canton especially in terms of government interventions to tourism.

\section{TOURISM IN BiH AND SARAJEVO CANTON PRIOR TO PANDEMIC}

$\mathrm{BiH}$ as a former Yugoslav member state has gained its independence in the early 1992, but due to the war in $\mathrm{BiH}$ (1992-1995) and the consequences it has left, still, twenty-five years after the end of war are not fully overcome. The most important legacy after the end of war in $\mathrm{BiH}$ is defined in its new Constitution under the Dayton Peace Agreement which organized country as two entities, $\mathrm{FBiH}$ and $\mathrm{RS}$ and one district (Brčko District). The latest Census data (2013) indicates that there are more than 3.5 million persons living in $\mathrm{BiH}$.

The most relevant two consequences of the new Constitution are:

- Under two entity's constitutions, tourism is under direct responsibility of the two entities. The system is even more complicated in $\mathrm{FBiH}$ since jurisdiction over tourism is divided between federal and cantonal level;

- The territorial position of Sarajevo has changed, in fact, the territory of Sarajevo has decreased. In the period prior to 1995, Sarajevo consisted of ten municipalities that formed the city. As of 1995, Sarajevo belongs to FBiH which is fiscally decentralized and includes ten cantons. Sarajevo Canton is one of the ten cantons whose territory and population has decreased under the new constitution. Several municipalities that formed city of Sarajevo until 1995 are now new municipalities created at the interentity borderline and these municipalities are usually very small, territory and population-wise.

Under new circumstances, the position of city of Sarajevo has changed into current Sarajevo Canton. There is no uniform strategy regarding tourism at the level of $\mathrm{BiH}$, so the tourism is fragmented.

Sarajevo Canton has remained an administrative, financial, and economic center of the country. In terms of the importance of the Sarajevo Canton as a tourist destination in $\mathrm{BiH}$ and $\mathrm{FBiH}$, in figure 1 we present the share of the incoming tourist arrivals of Sarajevo Canton to total arrivals in $\mathrm{BiH}$ and $\mathrm{FBiH}$ for the period 2014-2019. Figure 1 indicates stable trend over 2014-2016 (approx. 36 percent at the level of $\mathrm{BiH}$ and 50 percent at the level of $\mathrm{FBiH}$ ) and an increase since 2017. (Figure 1). 
ToSEE - Tourism in Southern and Eastern Europe, Vol. 6, pp. 607-621, 2021.

A. Peštek, L. Lazović-Pita, V. Pijalović: THE EFFECTS OF THE COVID-19 OUTBREAK ...

Figure 1: Share of Sarajevo Canton incoming tourist arrivals to total arrivals in $\mathrm{BiH}$ and FBiH, 2014-2019

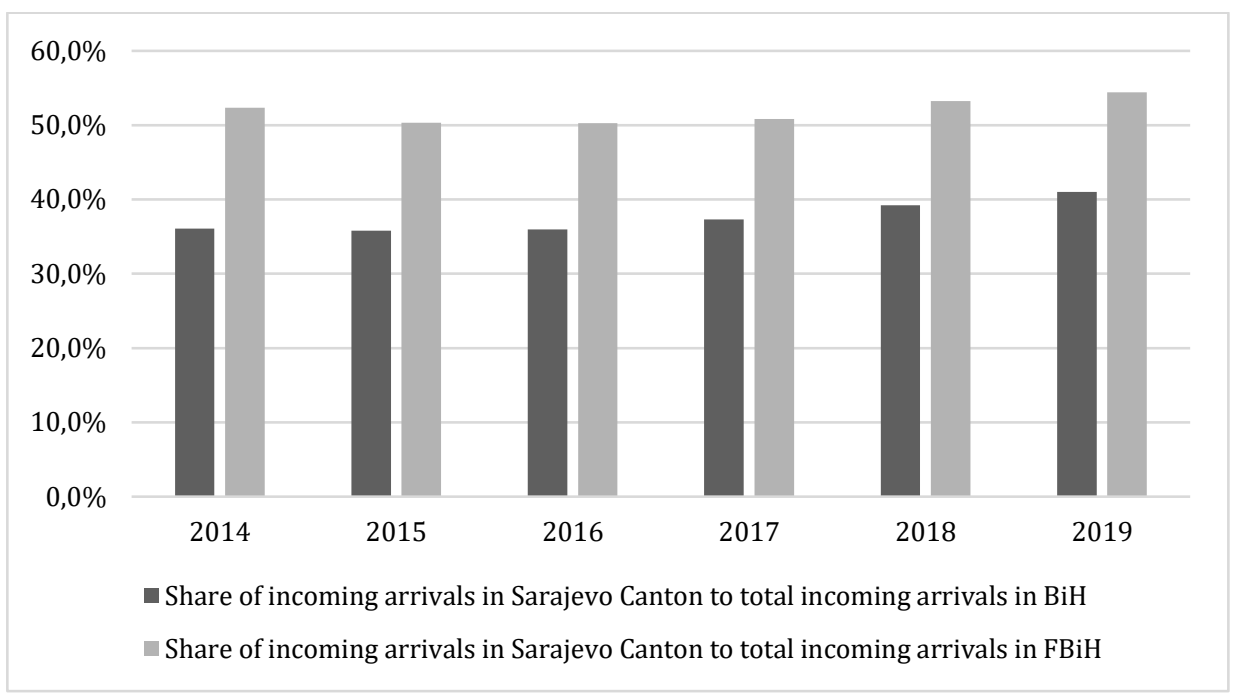

Source: Institute of statistics of $\mathrm{FBiH}$ and RS, 2020., own interpretation.

Over the observed period 2014-2019, the average share of incoming tourist arrivals of Sarajevo Canton to total arrivals in $\mathrm{FBiH}$ was 51.9 percent whereas the average share to total arrivals in $\mathrm{BiH}$ in the same period was 37.6 percent. If we look at the share of the incoming tourist arrivals in Sarajevo Canton to total incoming arrivals in $\mathrm{FBiH}$ in the long run (1999-2019), there has been a steady increase in Sarajevo Canton's share from 36 percent in 1999 to 55 percent in 2019 (Institute of statistics of $\mathrm{FBiH} 2020$ ). We assume that these figures are, similar to other indicators related to tourism, underestimated. This is primarily due to the presence of the gray economy and undeclared tourism enterprises, workers, and therefore generated income in the tourism in general since the presence of the undeclared economy is very much present in this industry (Williams 2021). Hence, in $\mathrm{BiH}$ too, all indicators and tourism-related statistics need to be carefully analyzed due to the presence of grey economy. However, they are useful in the identification of tourism-related trends. We consider that the figures are underestimated in the number of arrivals but not in the number of tourist overnight stays (nights).

The share of Sarajevo Canton incoming tourists nights to total nights in $\mathrm{BiH}$ and $\mathrm{FBiH}$ over 2014-2019 have also been presented in Figure 2. 
ToSEE - Tourism in Southern and Eastern Europe, Vol. 6, pp. 607-621, 2021.

A. Peštek, L. Lazović-Pita, V. Pijalović: THE EFFECTS OF THE COVID-19 OUTBREAK ...

Figure 2: Share of Canton Sarajevo incoming tourist nights to total nights in $\mathrm{BiH}$ and $\mathrm{FBiH}, 2014-2019$

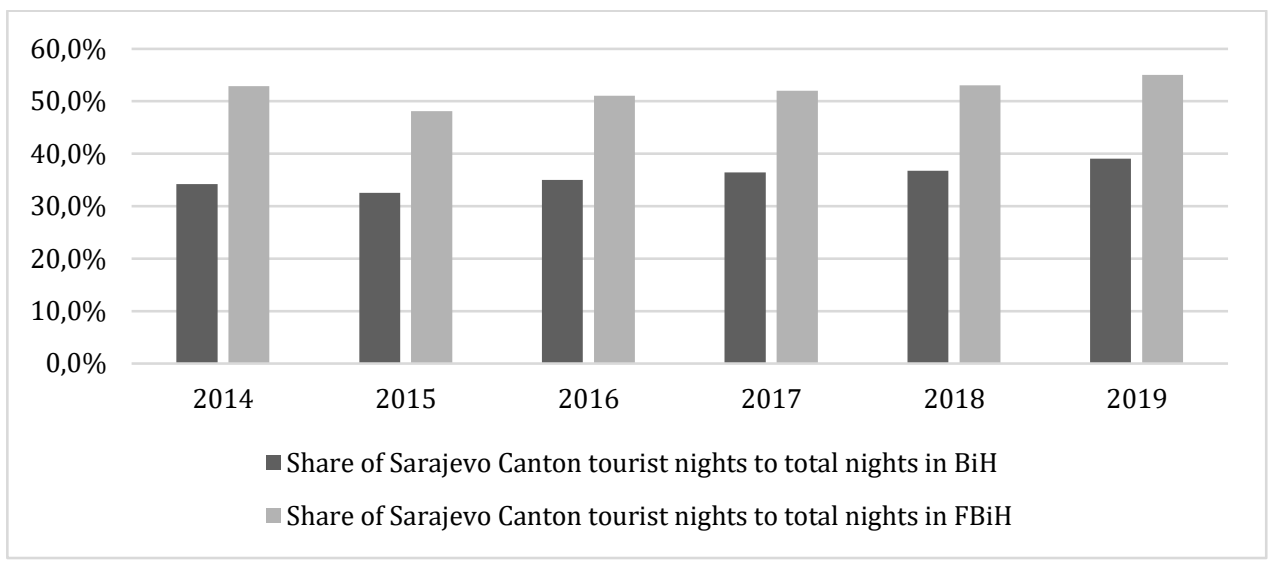

Source: Institute of statistics of FBiH and RS, 2020, own interpretation.

After a decline at the level of $\mathrm{BiH}$ and $\mathrm{FBiH}$ in 2014-2015, there has been a constant increase in the share of Sarajevo Canton tourist nights to total nights in $\mathrm{BiH}$ and $\mathrm{FBiH}$. On average (2014-2019), 52 percent of all tourist nights in FBiH are done in Sarajevo Canton and on average 35.7 percent of all tourist nights in $\mathrm{BiH}$. Again, in the long run (1999-2019), there has been a steady increase in the share of Sarajevo Canton tourist nights to total nights in $\mathrm{FBiH}$ from 33 percent in 1999 to 55 percent in 55 percent in 2019 (Institute of statistics of $\mathrm{FBiH} 2020$ ). Figure 3 shows a stable and an increasing trend in the number of tourist arrivals and nights in Sarajevo Canton over 1999-2019 period.

Figure 3: Tourist arrivals and tourist nights, Sarajevo Canton, 1999-2019, in thousands

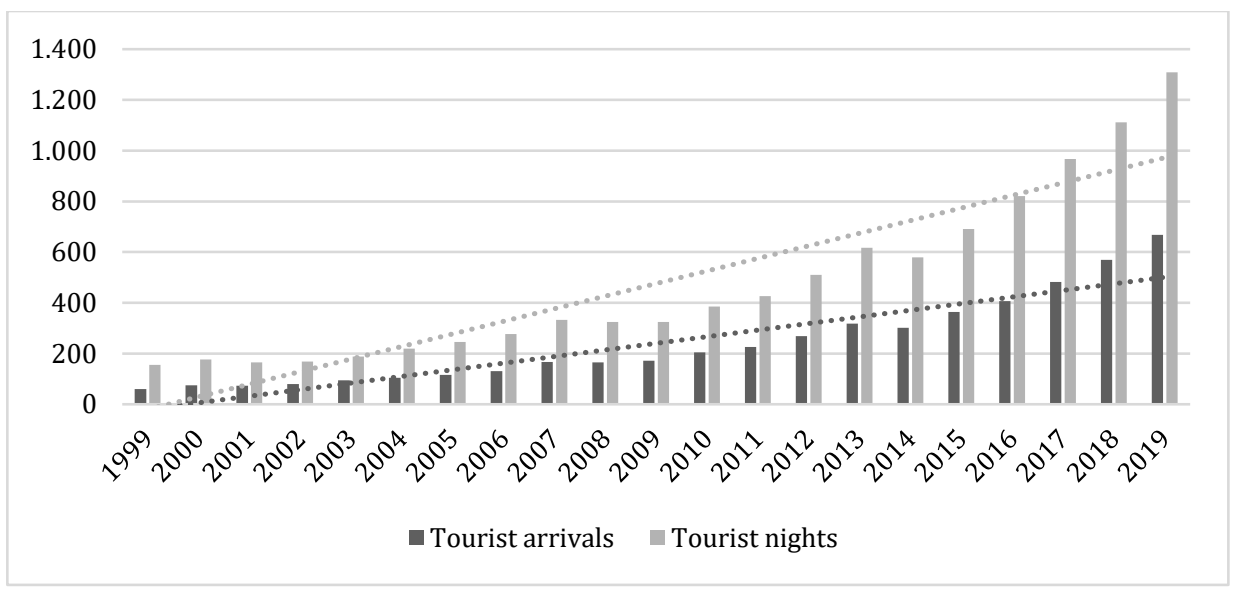

Source: Institute of statistics of $\mathrm{FBiH}, 2020$. 
ToSEE - Tourism in Southern and Eastern Europe, Vol. 6, pp. 607-621, 2021.

A. Peštek, L. Lazović-Pita, V. Pijalović: THE EFFECTS OF THE COVID-19 OUTBREAK ...

Hence, the importance of the analyzing the effects that the pandemic had on the tourism in Sarajevo Canton is very important since Sarajevo Canton generates the most arrivals and nights in the entire country. Within Sarajevo Canton, there is a high concentration of tourist activities in three municipalities: Stari Grad, Ilidža and Center. At the end of 2019, in Sarajevo Canton, 171 business units with accommodation capacities were registered, an increase by 60 percent compared to 2014 (Institute of statistics of $\mathrm{FBiH}$ 2020). Furthermore, at the end of $2019,6,053$ rooms with 13,529 beds were registered, which is an increase of 41 percent compared to 2014. Analysis of the data from Airbnb and Booking.com shows that there are unregistered renters, so the number of accommodation capacities is significantly higher. Accommodation facilities in Sarajevo Canton represent 25.6 percent of all accommodation facilities in $\mathrm{BiH}$ as shown on Booking.com. Accommodation capacity utilization in Sarajevo Canton in 2019 was 26.5 percent (Institute of statistics of $\mathrm{FBiH} 2020$ ), which is lower than in the EU.

Sarajevo Canton has a great potential for the development of various specialized tourism products that enable year-round tourism activities. However, this potential is not used adequately. Therefore, one of the basic features of the tourism in Sarajevo Canton is its seasonality marked by short stays of tourists. Almost all problems and challenges faced by tourism in $\mathrm{BiH}$ are reflected in the development of tourism in the Sarajevo Canton, and the situation in the development of tourism in $\mathrm{BiH}$ is best illustrated by the T\&T (Travel \& Tourism) index of the World Economic Forum. According to the T\&T index 2019, BiH ranks 105th out of 140 countries and lags significantly behind the countries in the region (WEF 2020).

Sarajevo Canton is in process of establishment of a development strategy of Sarajevo Canton for the period 2021-2027. After conducted workshops with stakeholders, the strategy identifies the main foundations of the development of the tourism in Sarajevo Canton due to its significance to cantonal economy. These are, inter alia, the importance and role of the city as the capital of the country, the growth of the number of tourist arrivals in FBiH and Sarajevo Canton, geographical location and good connections with other cities and regions, the proximity to large markets, unique cultural and historical heritage, and national monuments, i.e., tangible and intangible cultural heritage, natural resources, the popularity of the city of Sarajevo in the region, Baščaršija as a special attraction and symbol, hospitality of the population, food, the possibility of developing special interest tourism for certain target groups, unique crafts, specific events (Sarajevo Film Festival, Jazz Fest, MESS, Sarajevo Winter, etc.), complementary offer of other municipalities and other places in the area (spas, health tourism, congress tourism, winter tourism, mountain tourism, eco-tourism, etc.), and a tentative UNESCO list. The stakeholders also identified several deficiencies such as: the quality of tourism infrastructure is still underperforming tourist expectations, high share and presence of the gray economy in the industry, seasonality, and short stay of tourists, overlapping responsibilities of public authorities in the efficient destination management, underestimation in the official statistics due to the large number of unreported tourist nights, destination promotion does not meet its needs, lack of educated and qualified staff and tourism specialists, insufficient development and the threat of the extinction of crafts, and the quality of the overall tourism offer that is considered to be at the lower level than it ought to be. 
ToSEE - Tourism in Southern and Eastern Europe, Vol. 6, pp. 607-621, 2021.

A. Peštek, L. Lazović-Pita, V. Pijalović: THE EFFECTS OF THE COVID-19 OUTBREAK ...

Sarajevo Canton tourism mostly depends on international travelers and tourists (longhaul tourists). If we look at the structure of the incoming tourists by country of origin (top 10 countries, table 1), the data from 2019 in Sarajevo Canton reveals that more than 60 percent of tourist activity is created by international tourists, i.e., 62 percent of arrivals and 61.9 percent of nights.

Table 1: Top 10 incoming tourists by country of origin, tourist arrivals and nights in Sarajevo Canton, 2019.

\begin{tabular}{lrlr}
\hline Country & Arrivals & Country & Nights \\
\hline China & 66,392 & Saudi Arabia & 131,512 \\
Croatia & 60,159 & Croatia & 113,278 \\
Turkey & 51,201 & Turkey & 106,902 \\
S.Arabia & 46,849 & China & 99,041 \\
U.A.E. & 26,283 & U.A.E. & 93,851 \\
Germany & 23,392 & USA & 52,289 \\
Slovenia & 26,037 & Germany & 52,278 \\
Serbia & 21,653 & Slovenia & 48,387 \\
USA & 20,316 & Serbia & 41,633 \\
Italy & 16,881 & Italy & 40,958 \\
\hline Total & 359,163 & Total & 780,129 \\
\hline
\end{tabular}

Source: Tourism association of Sarajevo Canton, 2020.

The current situation in the development of tourism in Sarajevo Canton shows that the destination as a whole and thus the development of tourism has not been effectively managed. The development of tourism is currently the result of organic growth and initiative of primarily of the private industry. The private industry operates independently in the market with a small degree of integration within the industry. Furthermore, the level of cooperation between the private and the public industry is low.

Destination management and the absence of a strategic approach to the development of tourism ought to be considered as key shortcomings of the Sarajevo Canton as a destination. This fact has unfortunately been highlighted during the current COVID-19 pandemic.

$\mathrm{BiH}$ and Sarajevo Canton are far from realizing their full potential in tourism. The future of tourism in $\mathrm{BiH}$ and Sarajevo Canton are ought to be directed towards innovations in product development, better organization, and marketing. It is necessary to reengineer the entire tourism system and make a strategic move towards sustainable tourism based on efficient destination management.

\subsection{Tourism in BiH during the current COVID-19 pandemic}

The pandemic and lockdown decreased the share of international travelers travelling to $\mathrm{BiH}$ from $75 \%$ in 2019 to $44 \%$ in 2020 (January-September, Agency for Statistics BiH 2020). Tourist arrivals and tourist nights in 2020 (January-September) in $\mathrm{BiH}$ are at the level of $25.7 \%$ and $28.9 \%$ respectively of those in 2019 (Agency for Statistics BiH 2020). 
ToSEE - Tourism in Southern and Eastern Europe, Vol. 6, pp. 607-621, 2021.

A. Peštek, L. Lazović-Pita, V. Pijalović: THE EFFECTS OF THE COVID-19 OUTBREAK ...

These figures would be much lower if there were no positive developments in January and February 2020. The pandemics stopped a positive trend of growth of tourism in $\mathrm{BiH}$. The 2020 began promising by March 2020 but has been stopped since. Tourist arrivals and nights in $\mathrm{FBiH}$ in 2020 (January-September) are at the level of $24.4 \%$ and $29.4 \%$, respectively of those in 2019. The share of international travelers to $\mathrm{FBiH}$ decreased from $81 \%$ in 2019 to $43 \%$ in 2020. Tourist arrivals and nights in RS in 2020 (January-September) are at the level of $48 \%$ and $56.9 \%$, respectively of those in 2019. It is interesting to note that in relative terms decrease is lower in RS than in $\mathrm{FBiH}$. One of the reasons for that could be a higher share of domestic tourists in overall tourism activities in RS (44\%) than in $\mathrm{FBiH}(19 \%)$. Figure 4 shows the monthly breakdown of the tourist arrivals and nights in BiH from 2017 until 2020 (January until September, latest available data for 2020). Since there has been a sharp decrease in international travelers to $\mathrm{BiH}$, it is reasonable to expect a fall in number of arrivals and nights in Sarajevo Canton since it has been previously noted that Sarajevo Canton heavily depends on international tourists.

Figure 4: Monthly breakdown of the tourist arrivals in BiH, January-September, 2017-2020.

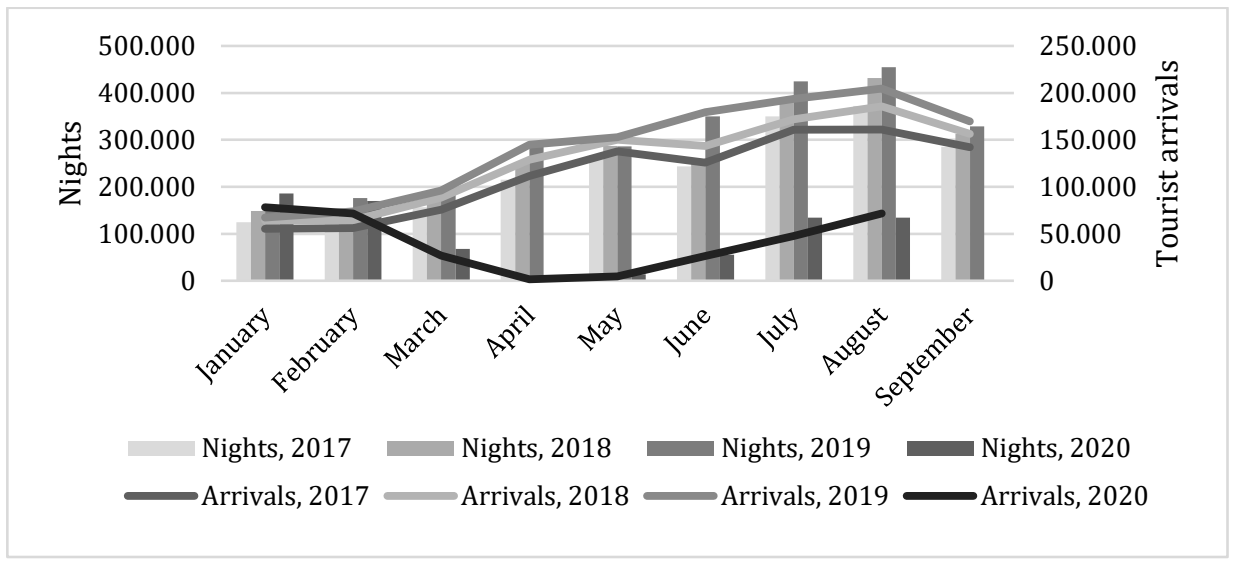

Source: Agency for statistics of $\mathrm{BiH}, 2020$

\section{METHODOLOGY AND SURVEY RESULTS}

For the purposes of the research, a survey aimed at tourism-related businesses in Sarajevo Canton was conducted in collaboration with the Tourism association of Sarajevo Canton. The survey was conducted in two waves: at the outbreak of pandemic in March 2020, and in September 2020. The research was conducted through an online structured questionnaire. The advantages of the online survey are reflected in wide geographical coverage, large coverage, fast location and availability of respondents, anonymity of respondents, speed of implementation, unification of procedures for collecting, entering, controlling, and correcting data, and cost rationalization. The survey was created on the Google Docs platform and was distributed via e-mail, the website of the Tourism association of Sarajevo Canton and social media profiles. Since the non-probabilistic online survey reduces the possibility of generalizing the results to the entire population, an e-mail 
ToSEE - Tourism in Southern and Eastern Europe, Vol. 6, pp. 607-621, 2021.

A. Peštek, L. Lazović-Pita, V. Pijalović: THE EFFECTS OF THE COVID-19 OUTBREAK ...

survey was also used for the purposes of this research. The survey was sent by e-mail to the Tourism association of Sarajevo Canton, together with a request for further distribution of the survey to the tourist businesses in Sarajevo Canton. The survey provided 233 correctly completed questionnaires (March 2020) and 126 (September 2020). The summary of the registered business activities of the respondents in both waves are summarized in table 2 .

Table 2: Registered business activity of the respondents in Sarajevo Canton, March and September 2020.

\begin{tabular}{lrrrr}
\hline Registered business activity of the respondents* & March & \%* & September \\
& 2020 & & 2020 & $\%^{*}$ \\
\hline Tourist agency (incoming i/ili outgoing) & 82 & 35.2 & 64 & 50.8 \\
Accommodation- apartments & 57 & 24.5 & 8 & 6.3 \\
Accommodation- hotels & 49 & 21 & 42 & 33.3 \\
Accommodation - hostels & 19 & 8.2 & 6 & 4.8 \\
Accommodation - other & 18 & 7.7 & 2 & 1.6 \\
Transport and organisation of transport. rent-a-car & 40 & 17.2 & 22 & 17.5 \\
Tourist guides & 39 & 16.7 & 26 & 20.6 \\
Restaurants. cafes. bars & 19 & 8.2 & 8 & 6.3 \\
Rural households & 4 & 1.7 & 2 & 1.6 \\
Other & 13 & 5.6 & 4 & 3.2 \\
\hline
\end{tabular}

*Multiple responses were possible.

Source: Authors.

The number of surveyed businesses in September 2020 is significantly lower than in March 2020. Possible reasons lie in the fact that many micro and small-size enterprises were forced to be closed during the March-September 2020 period. In the structure of surveyed businesses in March 2020, 54.5 percent were registered as small business. In the period 2016-2020, a growing number of tourist arrivals and nights was recorded and during that period, most small businesses were opened. About 49 percent of surveyed businesses in March 2020 only had sufficient financial resources to keep their businesses running for one month only. The surveyed period March-September 2020 is mostly characterized by insufficient government interventions and stimulus packages to the tourism. Surveyed data from March 2020 also indicates that for 64 percent of businesses, the share of foreign tourists to total incoming tourists was 80 percent and hence, the corresponding number of cancelations in 2020. 18 percent of the surveyed businesses faced the cancelation rate of 60 to 80 percent.

In terms of the expectations of the effects that the pandemic will have on their business operations, the respondents were pessimistic in both March and September 2020. The responses to the statement of the expected fall in the business operations by the end of 2020 compared to 2019 in both waves revealed a gloomy picture (Table 3). More than 80 percent of all respondents in both waves have forecasted (March) and recorded (September) a fall in their business operations due to the pandemic. The responses regarding the financial availability of the businesses to remain open and running in the next period also indicates unfavorable results. The available financial resources in March 2020 showed that 49 percent and 43 percent of the respondents have enough financial resources to keep the business running in less than a month and one to three months respectively. 
ToSEE - Tourism in Southern and Eastern Europe, Vol. 6, pp. 607-621, 2021.

A. Peštek, L. Lazović-Pita, V. Pijalović: THE EFFECTS OF THE COVID-19 OUTBREAK ...

In September 2020, the responses regarding a similar statement - whether the businesses have enough financial resources for normal functioning of the company revealed similar results, bearing in mind that 46 percent of the businesses interviewed in March 2020 were not operational in September 2020. In September 2020, 21 percent of respondents stated that they have enough financial resources to keep the business running in less than a month and 36.5 percent for one to three months (Table 3).

The severe impact that COVID-19 pandemic had on the tourism in Sarajevo Canton could be best interpreted through the following results. In March 2020, 27 percent of respondents considered that they would need up to three months to return their business operations to the level prior to the pandemic, and 30 percent estimated that they would require up to six months. In September 2020, only 1.6 percent considered they would need up to three months to return to normal, whereas 16 percent estimated that they would require up to six months. In comparison to March 2020 where only 9 percent of respondents estimated that they would need more than 12 months to return their business operations to prior-pandemic levels, in September 2020, 43 percent of respondents considered such move to be feasible (Table 3).

Table 3: The summary of responses of businesses in Sarajevo Canton - the severity of the impact of COVID-19, March and September 2020.

\begin{tabular}{lrr}
\hline A fall in business operations compared to & $\begin{array}{r}\text { Expected in March } \\
2019\end{array}$ & $\begin{array}{r}\text { Situation in September } \\
2020(233): \text { in } \%\end{array}$ \\
\hline $0-20 \%$ & 3 & \\
$21-40 \%$ & 2 & \\
$41-60 \%$ & 15 & \\
$61-80 \%$ & 37 & 11 \\
$81-100 \%$ & 42 & 89 \\
\hline Do you have enough financial resources & Expected in March & Situation in September \\
to keep your business running for: & 2020 (233): in \% & 2020 (126): in \% \\
\hline less than one month & 49 & 21 \\
one to three months & 43 & 37 \\
four to six months & 4.3 & 24 \\
seven to twelve months & 3.4 & 7 \\
more than 12 months & 0.4 & 5 \\
\hline How long would it take your business & & \\
operations to return to the level prior to & Expected in March & Situation in September \\
the pandemic? & 2020 (233): in \% & 2020 (126): in \% \\
\hline up to three months & 35.0 & 4.5 \\
from three to six months & 30.0 & 15.9 \\
six to twelve months & 24.0 & 25.4 \\
more than 12 months & 9.0 & 41.3 \\
more than 24 months & 2.0 & 12.7 \\
\hline
\end{tabular}

Source: Authors.

So, what could government interventions do and help the soaring effects that pandemic has left in the tourism in Sarajevo Canton and (F)BiH? In September 2020, respondents stated that the most problems in their business operations are related to the payments of the salaries and social security contributions (SSCs, 71 percent and 58.7 percent respectively) 
ToSEE - Tourism in Southern and Eastern Europe, Vol. 6, pp. 607-621, 2021.

A. Peštek, L. Lazović-Pita, V. Pijalović: THE EFFECTS OF THE COVID-19 OUTBREAK ...

closely followed by the collection of receivables and payments of communal charges (47.6 percent and 46 percent respectively, Table 4). To overcome such problems, businesses in tourism in Sarajevo Canton have decreased their costs (76 percent of responses) and prices of their services (52 percent). Unfortunately, businesses had to cut the costs by reducing salaries (51 percent) of the employees as well as make employees redundant (49.2 percent of responses, table 4). So, this gloomy picture could only be advanced with a help of active government interventions. In March 2020, tourism businesses in Sarajevo Canton expected that the government will help the industry by completely exemption from taxes, contributions, and other benefits (70 percent of responses), financing the part of the worker's salaries (56.3 percent of responses), direct financial assistance (56 percent of responses) and exemption of communal charge payments (50 percent of responses). However, in September 2020, the results reveal that tourism businesses received very few financial assistance and active government interventions - the financing of the worker's salaries (66.7 percent) and financial aid from the Tourism association of Sarajevo Canton (19 percent). Hence, the respondents in September 2020 considered that all government levels -from the level of institutions of $\mathrm{BiH}$, federal, cantonal to municipal together with Chambers of Commerce and Tourist Associations failed to provide support to the tourism during the pandemic. The mean score at all levels is on average 1 (the lowest) with some variation in the results.

Table 4: The summary of responses of tourism-related businesses in Sarajevo Canton - defined problems and possible government interventions

\begin{tabular}{lrr}
\hline $\begin{array}{l}\text { Problems faced by Sarajevo Canton businesses in the past six } \\
\text { months, September 2020 (126)*: }\end{array}$ & $\begin{array}{r}\text { March } \\
\text { 2020: in \% }\end{array}$ & $\begin{array}{r}\text { September } \\
\text { 2020: in \% }\end{array}$ \\
\hline payment of salaries & & 71.4 \\
payment of SSCs & & 58.7 \\
collection of receivables & & 47.6 \\
payments of communal charges & March & September \\
\hline Means of overcoming identified problems in the past six & 2020: in \% & 2020: in \% \\
months, September 2020 (126)* & & 76.2 \\
\hline decreasing the costs in the company & 52.4 \\
fall in prices & & 50.8 \\
reducing salaries & March & September \\
making employees redundant & $2020:$ in \% & $2020:$ in \% \\
\hline What are expected government interventions in the tourism? & 69.7 \\
March, 2020 (233)* & 56.3 & \\
\hline complete exemptions of taxes, SSCs and other charges & 55.8 & \\
financing the part of the worker's salaries & 50.6 & \\
direct financial assistance & 49.8 & \\
financing of the worker's minimum salary & March & September \\
exemption of communal charge payments & & 66.7 \\
\hline What government interventions in the tourism did you receive? & 2020. in \% & 2020. in \% \\
September, 2020 (126)* & & 19 \\
\hline the financing of the worker's salaries & & 14,3 \\
financial aid from the Tourism association of Sarajevo Canton & & 28,6 \\
deferral of loan payments & \\
no financial assistance received & & \\
\hline
\end{tabular}

*Multiple responses were possible.

Source: Authors. 
ToSEE - Tourism in Southern and Eastern Europe, Vol. 6, pp. 607-621, 2021.

A. Peštek, L. Lazović-Pita, V. Pijalović: THE EFFECTS OF THE COVID-19 OUTBREAK ...

\section{CONCLUSION AND RECOMMENDATIONS}

The 2020 season in Sarajevo Canton according to the presented data is considered unsuccessful. The COVID-19 pandemic restricted and limited travel which had devastating effects on the tourism in Sarajevo Canton. Furthermore, tourism-related businesses do not have clear plans how to overcome the crisis nor the financial resources to maintain the level of business. The tourism-related businesses expected several financial stimulus packages from the government as well as help from the Tourism association of Sarajevo Canton and the banks. The severity and the hardship of the impact of the pandemic in Sarajevo Canton can be specifically seen in the case of micro and small businesses, which began to expand after 2015 but now are either closed or at risk of closing.

Our survey results also revealed that there is an obvious disparity in the expectations and the scope of support received. Therefore, it is not surprising that there is a relatively low level of business optimism and satisfaction in tourism-related businesses in Sarajevo Canton with the government interventions at all levels (central and sub-central). Unfortunately, what remains certain is the fact that after the end of the pandemic, there will be no rapid recovery of the tourism.

The coronavirus pandemic has clearly revealed many problems that the tourism in Sarajevo Canton has been facing for many years, primarily in terms of the development of tourism enabling environment and business enabling environment. It is to be expected that the crisis will lead to a change in the behaviour of both business and the public industry, in terms of destination management development, strengthening cooperation, innovation in the development of integrated tourism and the necessary strategic development on the principles of sustainable tourism. That is, strategic development reengineering of the entire tourist system is needed. The development of tourism requires better state support and cooperation (at different levels - the state of $\mathrm{BiH}, \mathrm{FBiH}$ and the canton) and active involvement of stakeholders from the public industry, but also integration and cooperation within the private industry.

Our findings showed that the tourism in Sarajevo Canton is highly dependent on foreign tourists, especially from the long-haul market, which will prolong the recovery period. Shifting the focus to short-haul tourists is one of the possible development options.

\section{REFERENCES}

Agency for statistics of $\mathrm{BiH}$ (2020), Tourism in numbers, viewed 25 ${ }^{\text {th }}$ March 2021, http://www.bhas.ba/Calendar/Category/19

Apaza-Panca, M., Cynthia, S.C.A., Elena, J., Maquera-Luque, J. and Pedro, T.C. (2020), "Rethinking Tourism Public Policies to mitigate the effects of Covid-19”, Cuestiones Politicas, Vol. 38, No. 66, pp. 119133.

Cai, G., Hong, Y., Xu, L., Gao, W., Wang, K. and Chi, X. (2021), “An Evaluation of Green Ryokans through a Tourism Accommodation Survey and Customer-Satisfaction-Related CASBEE-IPA after COVID-19 Pandemic", Sustainability, Vol. 13, No. 1, 145. doi: 10.3390/su13010145

Elgin, C., Basbug, G. and Yalaman, A. (2020), "Economic policy responses to a pandemic: Developing the COVID-19 economic stimulus index", Covid Economics, Vol. 1, No. 3, pp. 40-53. 
ToSEE - Tourism in Southern and Eastern Europe, Vol. 6, pp. 607-621, 2021.

A. Peštek, L. Lazović-Pita, V. Pijalović: THE EFFECTS OF THE COVID-19 OUTBREAK ...

Foo, L.P., Chin, M.Y., Tan, K.L. and Phuah, K.T. (2020), "The impact of COVID-19 on tourism in Malaysia”, Current Issues in Tourism, Vol. 24, No. 19, pp. 2735-2739. https://doi.org/10.1080/13683500.2020.1777951

Galvani, A., Lew, A.A. and Perez, M.S. (2020), "COVID-19 is expanding global consciousness and the sustainability of travel and tourism", Tourism Geographies, Vol. 22, No. 3, pp. 567-576. https://doi.org/10.1080/14616688.2020.1760924

Grech, V., Grech, P. and Fabri, S. (2020), "A risk balancing act-tourism competition using health leverage in the COVID-19 era", International Journal of Risk \& Safety in Medicine, Vol. 31, No. 3, pp. 121130. doi: $10.3233 /$ JRS-200042

Institute of Statistics of FBiH (2020), Kanton Sarajevo u brojkama 2020, viewed 12 February 2021, https://fzs.ba/wp-content/uploads/2021/02/KS_2020.pdf.pdf.

Institute of Statistics of Republika Srpska (2020), Statistical yearbook of 2020, viewed 12 February 2021, https://www.rzs.rs.ba/front/article/4582/?left_mi=None\&add=None.

Ioannides, D. and Gyimothy, S. (2020), "The COVID-19 crisis as an opportunity for escaping the unsustainable global tourism path", Tourism Geographies, Vol. 22, No. 3, pp. 624-632. https://doi.org/10.1080/14616688.2020.1763445

Khalid, U., Okafor, L.E. and Burzynska, K. (2021), "Does the size of the tourism influence the economic policy response to the COVID-19 pandemic?", Current Issues in Tourism, Vol. 24, No. 19, pp. 28012820. https://doi.org/10.1080/13683500.2021.1874311

Knight, D.W., Xiong, L., Lan, W. and Gong, J. (2020), "Impact of COVID-19: research note on tourism and hospitality industrys in the epicenter of Wuhan and Hubei Province, China", International Journal of Contemporary Hospitality Management, Vol. 32, No. 12, pp. 3705-3719. https://doi.org/10.1108/IJCHM-04-2020-0278

Kopytowska, M. and Krakowiak, R. (2020), "Online incivility in times of Covid-19: Social disunity and misperceptions of tourism in Poland”, Russian Journal of Linguistics, Vol. 24, No. 4, pp. 743-773. https://doi.org/10.22363/2687-0088-2020-24-4-743-773

McKinsey \& Company (2020), COVID-19 tourism spend recovery in numbers, viewed $25^{\text {th }}$ March 2021 , https://www.mckinsey.com/industries/travel-logistics-and-infrastructure/our-insights/covid-19tourism-spend-recovery-in-numbers

OECD (2020a), COVID-19 Crisis Response in South East European Economies, viewed 10 February 2021 https://read.oecd-ilibrary.org/view/?ref=129_129649-tclugxbw4j\&title=COVID-19-CrisisResponse-in-South-East-European-Economies

OECD (2020b), The COVID-19 crisis and BiH, viewed 15 December 2020, http://www.oecd.org/south-easteurope/COVID-19-Crisis-in-Bosnia-and-Herzegovina-archive.pdf.

Quang, T.D., Tran, T.C., Tran, V.H., Nguyen, T.T., and Nguyen, T.T. (2020), "Is Vietnam ready to welcome tourists back? Assessing COVID-19's economic impact and the Vietnamese tourism's response to the pandemic", Current Issues in Tourism, 1-19. https://doi.org/10.1080/13683500.2020.1860916

Tourism Association of Sarajevo Canton (2020), Annual Report for 2019, Sarajevo.

UN World Tourism organization (2020), Tourism and COVID-19-Unprecedented Economic Impacts, viewed 18 January 2021, https://www.unwto.org/tourism-and-covid-19-unprecedented-economicimpacts\#: :text=Export\%20revenues\%20from\%20tourism\%20could,both\%20developing\%20and $\% 20$ developed $\% 20$ economies

Williams, C.C. (2021), "Impacts of the coronavirus pandemic on Europe's tourism: Addressing tourism enterprises and workers in the undeclared economy", International Journal of Tourism Research, Vol. 23, No. 1, pp. 79-88. https://doi.org/10.1002/jtr.2395

World Economic Forum (2020), The Travel and Tourism Competitiveness Report 2019, viewed 15 March 2021, https://www.weforum.org/reports/the-travel-tourism-competitiveness-report-2019. 
ToSEE - Tourism in Southern and Eastern Europe, Vol. 6, pp. 607-621, 2021.

A. Peštek, L. Lazović-Pita, V. Pijalović: THE EFFECTS OF THE COVID-19 OUTBREAK ...

Almir Peštek, PhD, Professor

School of Economics and Business, University of Sarajevo

Department of Marketing

Trg oslobodjenja 1, 71000 Sarajevo, $\mathrm{BiH}$

+38733275958

almir.pestek@efsa.unsa.ba

Lejla Lazović-Pita, $\mathrm{PhD}$, Associate professor

School of Economics and Business, University of Sarajevo

Department of Finance

Trg oslobodjenja 1, 71000 Sarajevo, $\mathrm{BiH}$

+38733275998

lejla.lazovic@efsa.unsa.ba

Velma Pijalović, $\mathrm{PhD}$, Associate professor

School of Economics and Business, University of Sarajevo

Department of economic theory and policy

Trg oslobodjenja 1, 71000 Sarajevo, $\mathrm{BiH}$

+38733253760

velma.tahmaz@efsa.unsa.ba 